\title{
Interdisciplinary Research on «Global Environmental Change» at the Department of Geosciences/Geography of the University of Fribourg
}

Martin Beniston, Claude Collet, Thomas Hammer, Walter Leimgruber, Michel Monbaron, Jean Ruegg, Fribourg

\section{Introduction}

Global environmental change can be defined as a series of stress factors on the physical and biological systems of the planet. The Earth's environment is continuously subjected to various stresses through natural processes and human interference. Global change is not a new concept, but with the rapid industrialization and population growth that the $20^{\text {th }}$ century has witnessed worldwide, the natural environment has undergone unprecedented changes. In some instances, environmental degradation is inevitable because of the basic requirements of human populations, particularly where those are growing rapidly; in other cases, environmental damage is a direct result of mismanagement and over-exploitation of natural resources. The consequences of such degradation are sometimes not recognized or are often ignored because of the perceived higher benefits of economic gain.

Whether the global environment is capable of withstanding natural and anthropogenic stresses is a matter of constant debate. In some instances, the environment has - at least on local to regional scales - been able to revert to its previous levels. Examples of such resilience abound: the acidity of lakes in Northern Ontario, Canada, reverted to their natural levels following significant abatement of sulfur-based pollution from a major smelting plant. In other instances, environmental damage appears to be irreversible, such as the large perimeter of contaminated lands following the 1986 nuclear accident in Tchernobyl, Ukraine, or the deforestation of pristine jungles in many tropical regions. Examples of irreversible degradation have provided arguments to those who believe that environmental impacts are cumulative and difficult to reverse. A third paradigm is that there are certain beneficial effects of stresses on the environment, namely that ecosystems become resilient and can therefore withstand further and possibly greater stresses in the future. Forest fires, for example, are not solely a devastating phenomenon: they also return essential nutrients to the soil, allowing vigorous regeneration to occur. Indeed, some environments can maintain themselves in the long term only through fire.
All these paradigms are based on the assumption that the time scales associated with environmental change are long and that, in many situations, the environment may find a new equilibrium, if not its original state. Environmental upheavals have occurred in the past, along with species extinction, and yet the planet has «survived» and evolution has continued. However, it is possible that anthropogenic pressures are accelerating change and that many systems may not adapt to rapid rates of change, even if they could adapt to the amplitude of change over longer time periods.

Under the heading of global environmental change, one can list the following contributing factors, many of which are essentially human-induced:

- Air pollution and ozone depletion

- Climatic change

- Land degradation

- Deforestation

- Desertification

- Loss of biodiversity

- Fresh water shortage

- Hazardous wastes

- War

- Poverty.

There are two governing causal mechanisms that, broadly speaking, account for human interference on the natural environment, namely economic growth and demography. The economic level of a country determines to a large extent its resource requirements, in particular energy, industrial commodities, agricultural products and fresh water supply. Demography, on the other hand, is a critical factor in the sharing of the resources available to a particular country or set of countries.

High economic levels are resource-intensive, and this frequently leads to environmental degradation because of the resources required to maintain a high standard of living. Energy use per capita in the United States is 350 times greater than in Ethiopia or Rwanda, for example. Technology is today still energy-intensive, particularly in the transportation sector where fuel demand for road and air transportation continues to grow rapidly. Technology as used in the industrialized countries, along with the image of «western lifestyles» is often replacing traditional consumption and resource-use patterns in the developing world, even 
though traditional methods are often better adapted to local conditions. As a consequence, environmental concerns become a very low priority as economic survival becomes the dominant objective.

High population growth, on the other hand, can also lead to environmental damage as the inhabitants of poor countries attempt to maintain or improve their current economic level through the exploitation of their resources often without any long-term planning or management. While in most of the industrialized world, population growth is low (often less than 1\%), in some developing countries, demography is such that economic levels are dwindling. Kenya, for example, has a rate of population growth of around $4.3 \%$ per annum, which implies that if this is sustained, its population will double within a time-frame of 17 years. In order to simply maintain present economic levels, Kenya would need to double its existing infrastructure (energy supply, housing, schools, hospitals) and food and water supply within this very short time-frame. Such pressing demands on an already depressed economy represent a challenge that the most affluent countries would not be able to meet. The general lowering of a population's standard of living means that economic survival takes place at the expense of environmental protection, management and planning.

The current trends of globalization of economic markets and highly liberalized economies are not always compatible with environmental concerns. Present-day economic policies are often short-term (from a few days to a few months), whereas environmental management is by essence long-term (several years to several decades). Environmental protection is sometimes perceived to be contrary to free trade; indeed, attempts to slow down and possibly reverse tropical deforestation are considered in some circles to be contravening the World Trade Organization (WTO) accords on free trade. In the context of economic recession as experienced in many industrialized countries in the 1990 s, environmental protection is sometimes seen as a menace to job security. However, environmental assessments leading to protection and reclaiming has also led, in many instances, to new opportunities for economies and employment.

Because many actors in the economic and industrial arena tend to believe that the natural environment has no intrinsic value, there is often little incentive towards environmental protection or management, since the environment is perceived as an unlimited resource to be utilized in order to sustain economic growth. In the United States, there is increasing pressure from industrial lobbies for access to resources in some of the National Monuments and National Parks. There is the fear by environmentalists that allowing even limited rights for mining and oil prospection in protected areas such as Death Valley National Park (California), or in the more recent parks of Alaska, could set a precedent whereby the protection of these parks would become meaningless at some point in the future. Exploitation of raw materials by major manufacturing firms is a direct threat to indigenous people in different parts of the world; it is estimated that about 300 million people live in regions which account for about $60 \%$ of the world's natural resources.

Globalization is leading to a real or perceived trend of weakening of policy-making at the national level. Because major economic and financial decisions are taken outside a purely national framework, the ability of politicians to respond to such decisions is reduced. Politics, which up till recently was the driving force behind the nation-state, is today increasingly involved in economic management. So powerful is the wave of globalization that most policymakers are more concerned with economic affairs than environmental issues. They also are sensitive to shifts in the priorities of the general public, which is today more preoccupied by economic conditions than by the environment. In the industrialized countries, unemployment, crime, health insurance are all considered more pressing issues than those pertaining to environmental matters. In the developing world, food security and access to basic commodities and health are perceived as being far more urgent issues than a healthy environment.

Whatever the perception, it is highly likely that global environmental change will lead to lasting degradation and damage. This will in turn reduce the capacity of human societies to maintain their lifestyles at current levels, in particular because the driving forces of global economy may no longer be able to use the resources which the environment provides in a sustained manner. Regional disparities between rich and poor, which have always existed, will be exacerbated in a degraded environment. Issues related to global change highlight the general difficulty of society to use the limited resources of the planet in a rational manner, and to share equitably the essential commodities that the environment provides.

It is against this background of complex and subtle linkages between social, economic, physical and biological systems that the Geography Unit of the Department of Geosciences at the University of Fribourg has, over the last few years, addressed the challenges of the $21^{\text {st }}$ century, through an institutional interdisciplinarity that involves physical geography, human geography, and geomatics.

The different geographical domains represented in Fribourg will be briefly expanded upon below. 


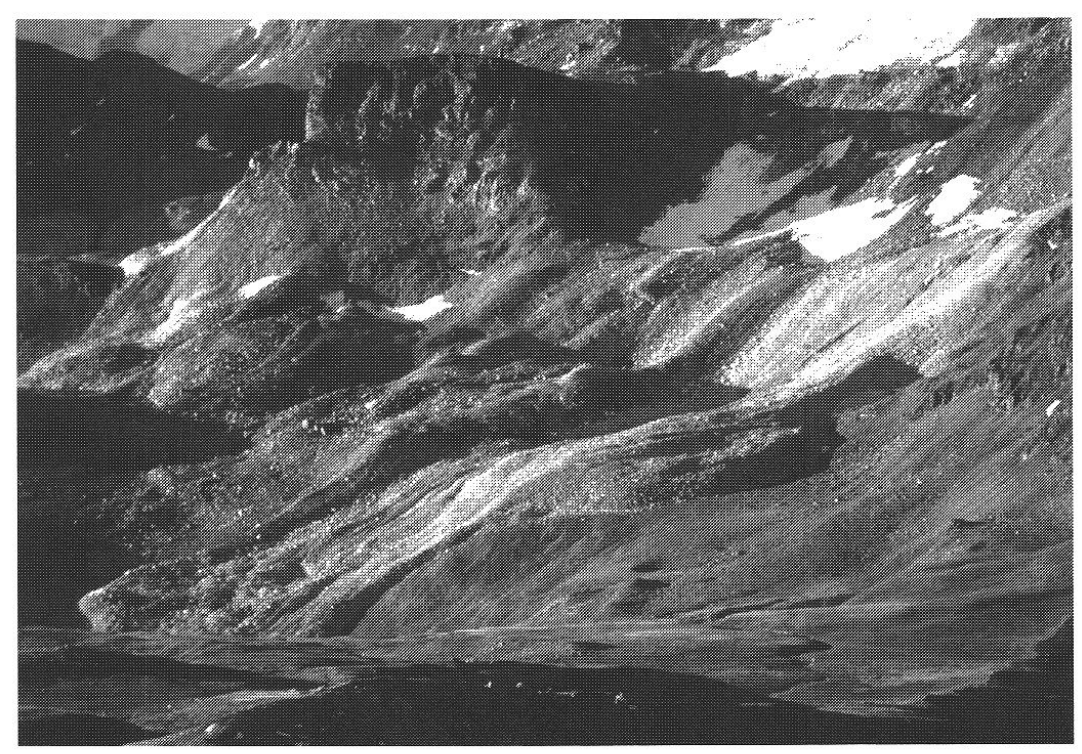

Fig. 1: The Lona glacier/rock glacier complex in the Valais Alps

Explanation: The snout of the formation consists of permanently frozen ground pushed down by a glacier that advanced during the Little Ice Age. Electrical measurements were carried out in this area in 1991. A strong degradation of the frozen ground was observed when repeating the measurements in 2002. The thawing of permafrost is the consequence of the historical dynamics of the formation.

Der Lona Gletscher/Felsgletscher-Komplex in den Walliser Alpen

Le glacier Lona/un complexe rocheux glaciaire dans les Alpes valaisannes

Photo: R. Delaloye

\section{Physical Geography at the University of Fribourg}

There are two main thrusts in the domain of physical geography, namely geomorphology and climate research.

For many years, investigations by the Group for Geomorphologic Research (GReG: Groupe de Recherche en Géomorphologie) of the Department of Geosciences have essentially focused on the in situ observation of natural phenomena, and the subsequent interpretation of these observations. Such research is based on numerous measurement campaigns in the field, and mapping and geomorphologic assessments that yield detailed environmental and landscape information, that in turn can lead to proposals for the management of the natural heritage. The research conducted by the GReG is determined by the natural characteristics of a number of Swiss regions, in particular the cantons of Jura and Fribourg, and also the alpine domains of Valais or Grisons. In these various cantons, local and/or federal agencies are in constant need of scientific information on such issues. The participation in environmental impact studies, in actions aimed at highlighting the value of natural sites and monuments of regional, cantonal and federal interest (the so-called geotopes), and also in long-term environ- mental observation networks, allows to bridge the gap between fundamental and applied aspects of environmental science requested at local government levels and by the general public. This research also allows the establishment of closer ties between scientists and graduate students through specific studies leading to Masters-level theses, thereby allowing students to gain practical experience for their future professional careers.

Research on alpine permafrost has been an ongoing theme for about 15 years at the University of Fribourg. Early research focused on the assessment of the geographical boundaries of permafrost in Switzerland and the description of typical periglacial forms such as rock glaciers (Tenthorey 1993; Gerber 1994; GardaZ 1998; Lugon 1998; Delaloye \& Morand 1998). Current research is now aimed at studying the occurrence and the evolution of permafrost in marginal zones (Delaloye \& Devaud 2000; Turatti 2002; Delaloye et al. 2003; Reynard et al. 2003). The setting up of the PERMOS long-term alpine permafrost monitoring network in Switzerland, in which the Fribourg group has played an active role (VoNDER MüHLL et al. 2001), paves the way for innovative research related to the medium-to-long term behavior of perennially-frozen grounds in the face of external forcings, in particular 
climatic change and the shifts in environmental conditions that these entail. In this field, the GReG works in close collaboration with the research team on permafrost processes led by Prof. W. HAEBERLI at the University of Zurich, and more particularly with the Institute of Geography of the University of Lausanne (Dr. E. REYNARD) (Fig. 1):

Since the year 2000, a research team has been set up in the field of dendro-geomorphology that is unique to Switzerland, with close links to the well-known dendroecology unit of the Swiss Federal Institute for Forest, Snow and Landscape research (WSL, Birmensdorf). The observation of the dendrological characteristics of trees and roots located in regions exposed to natural hazards (e.g. landslides, rockslides, avalanches, and debris flows) allows the application of dendro-ecological concepts to the understanding of these hazards and their frequency of occurrence (GärTNER \& STOFFEL 2002; GärtNer et al 2003; STOFfel et al 2003). Such research is favorably viewed by local authorities, which require scientific assessments of natural hazards to adequately plan risk management strategies (Bloetzer et al. 1998; Stoffel 1999; Stoffel 2000; Stoffel \& Monbaron 2000). The applicability of this new avenue is also of interest in the capacity building of students and young scientists (CONUS 2002; LIÈvRE 2002).

Several years of research related to the protection of geotopes have motivated numerous students and young scientists in Fribourg to pursue work in this domain. Cantonal authorities such as those of Fribourg and Jura requested an inventory of geotopes in their respective cantons in order to adopt strategies aimed at their protection. This led to the first doctoral thesis of its kind (GrandGIRARD 1997), subsequently paving the way for a number of Masters' level theses on the topic (Baudraz 1998; BoÉchat 2002; Dubey 1998; Froidevaux 2002; Menoud 1997). These studies often lead to proposals for didactic footpaths, aimed at informing the public about natural curiosities, in particular of a geological or geomorphologic nature, and the complex processes that led to their current presence and aspects (Betrisey 1997; JeANBourquin 1999; Lehmann 1997; Pedrazzini 2002; Reber 2001). Such studies are a necessary component that help in raising the awareness of the general public to issues of environmental protection and sustainable resource use; graduate students, through their knowledge base, can already contribute usefully to such information transfer.

Geomorphologic research in Fribourg has also a longstanding component related to the study of karst features and processes (Perritaz 1995; Boyer et al. 1998; Perritaz \& Monbaron 1998; Fierz \& Mon-
BARON 1999). Over the last two decades, karst-related research has declined with only one university department working in this domain; however, the recent creation of the Swiss Institute for Speleology and Karstology (ISSKA, a non-university research consortium) in La Chaux-de-Fonds has provided new impetus for karst studies (HäUSELMANN et al. 2003; HäUSELMANN $\&$ Monbaron 2001). New collaborations between the GReG and ISSKA have emerged through doctoral (HäUSELMANN 2002) or Masters-level theses. In addition, the construction of the Swiss national highway A16 «Transjurane» through territory that is predominantly of karstic nature in the Jura Mountains, has called for a number of environmental impacts studies in which the geomorphology group at the University of Fribourg has been involved.

Geomorphologic research in Fribourg thus consists of themes that bridge the gap between fundamental and applied research at the regional level (in order to respond to questions posed by local authorities), involving graduate students and young scientists, and information transfer to the general public to help raise their awareness of problems related to the management of natural systems. These different aspects converge towards the central theme of research in the Geography Unit of the Department of Geosciences, namely addressing the very diverse aspects of global environmental change discussed in the introduction to this paper.

In the domain of climatic change, a number of projects are currently under way, funded inter alia by the new NCCR-Climate and a major EU program (PRUDENCE) in the context of the $5^{\text {th }}$ Framework Program on Environment and Climate.

The climate research group at the Department of Geosciences of the University of Fribourg has developed over the past few years a strategy for climaterelated investigations, and in particular those related to extreme events. In many instances, environmental systems such as hydrology, snow, or vegetation, and socio-economic systems such as agriculture or human health are far more vulnerable to extreme events and climatic variability than to changes in mean climatic conditions. Current research aims at contributing to international efforts in the field of extreme events, and provides updated information on questions posed by the Intergovernmental Panel on Climate Change (IPCC) and by the United Nations Framework Convention on Climate Change (FCCC) that Switzerland ratified in 1993.

The main thrust of climate-related activities at the Department of Geosciences is related to regional climate modeling. The physical-mathematical compu- 
ter modeling approaches require large computational resources and a network of scientists both within Switzerland and in international circles. In this context, a research and teaching agreement was signed at the Rectors' level in 1999 by the University of Fribourg and the University of Quebec in Montreal (UQAM). This formal agreement is aimed at allowing exchange of scientists and students interested in climate issues between the two universities; indeed, the UQAM Atmospheric Sciences Department has been instrumental in the development of the numerical regional climate model CRCM-2 that is currently used at the University of Fribourg.

Individual research projects related to climate issues include:

- Numerical modeling of extreme events, funded by the NCCR-Climate;

- Assessment of the risks to forests and slope stability in the face of enhanced extreme events, funded by the Swiss Agency for Environment, Forests and Landscape (BUWAL), as a governmental contribution to the NCCR-Climate;

- Numerical modeling and remote sensing of current and future hailstorm events, funded by the Department of Geosciences;

- Assessment of shifts in climatic extremes (storms, heat waves, cold spells, floods and droughts) in Europe between current climate and future climate (period 2071-2100) on the basis of a suite of numerical regional climate models, funded by the EU $5^{\text {th }}$ Framework Program (PRUDENCE project);

- Response of alpine vegetation to future changes in snow-pack, funded by the Department of Geosciences;

- Methodologies for bridging the gap between regional climate model results at intermediate spatial resolution with snow, ice, and permafrost models at high spatial resolution, funded by the COST-719 project;

- A special contract with the European Southern Observatory (ESO) aimed at developing a computer decision-making tool for assessing the climatic characteristics of geographical locations of ESO's future 100-m telescope;

- Investigations of the relationships between climate and health, through the analysis of the atmospheric dispersal of allergenic pollens at various spatio-temporal scales.

This coordinated effort within our Department has the aim of understanding the fundamental mechanisms that link extremes and «mean climatic conditions». However, a further objective of the climate group in Fribourg is to attempt truly interdisciplinary research, which can be of value to a number of end-users, particularly those working in the fields of climatic impacts research, and the policy-making sphere. In terms of impacts research, there exists both internal and external collaboration in fields ranging from permafrost response to global warming, to shifts in vegetation or to the impacts of global change on tourism in the Alps. Such activities are of interest to both the private and the public sectors, in particular insurance companies who are concerned about possible increases in the frequency and severity of climate-related extremes, local authorities who need to develop regional adaptation strategies in the face of increasing threats related to natural hazards, and Federal agencies involved in the negotiations of the Framework Convention on Climate Change (FCCC). Increasingly, climate-related research within the Department of Geosciences is tending towards interdisciplinary research aimed at strengthening our ties with the «end-user» community who today have urgent requirements for reliable, highresolution climate information (Fig. 2).

In addition to these fundamental research activities, the climate research group also promotes information transfer to the Swiss government, in the context of the IPCC (Intergovernmental Panel on Climate Change, for which M. Beniston was one of the vice-chairpersons from 1993-1997) and the continued requirements for scientific results of relevance to the negotiation and implementation process related to the Kyoto Protocol (an international agreement within the UN Framework Convention of Climate Change signed in 1997). Furthermore, scientific workshops are held on an annual basis to address issues of global change research (the Wengen Workshops on Global Change Research. Information can be found on URL: http://www.unifr.ch/geoscience/geographie/ Personal/MB/mb.html\#WWGCR), in partnership with leading institutions. Topics at the Wengen Workshops since 1995 range from fundamental research in highresolution climate modeling, to the impacts of environmental and climatic change on water resources, forests, mountain regions, population migrations, and to science and policy issues linked to the Kyoto Protocol, for example. A final contribution to the dissemination of results is through a book series entitled «Advances in Global Change Research» published simultaneously in The Netherlands and the United States by Kluwer Academic Publishers (series editor: M. BENISTON. Information can be found on URL: http://www.unifr.ch/geoscience/geographie/ Personal/MB/mb.html\#kluwer2).

For further details see BENISTON 1997, 2000a, 2000b, 2001a, 2001b, 2002a, 2002b, 2003, 2002c; BeNISTON, Casals \& Sarazin 2002; Beniston, Diaz \& Bradley 1997; Beniston, Fox, Adhikary, Andressen, Guisan, Holten, Innes, Maitima, Price \& Tessier 1996; Beniston, Haeberli \& Taylor 1997; Beniston \& HaeBerli 2001; Beniston \& InNes 1998; Beniston \& 

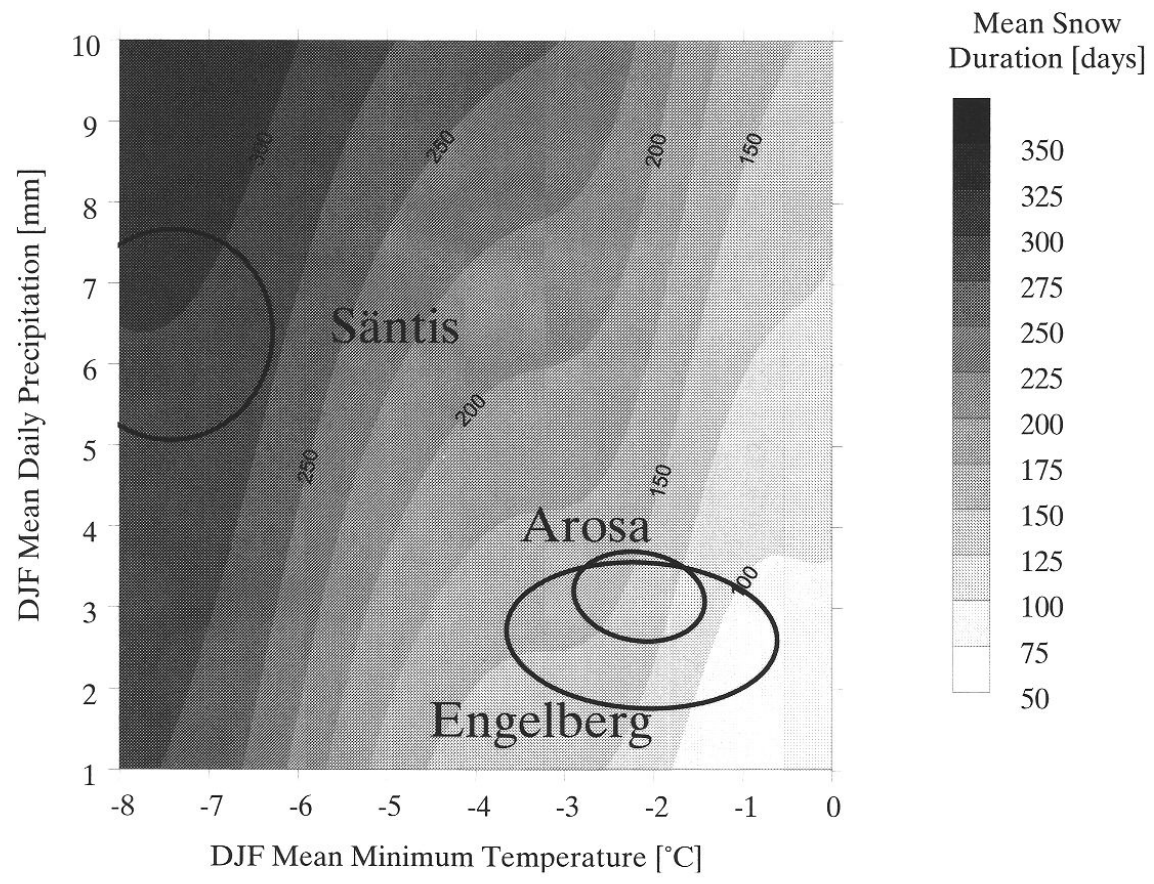

Fig. 2: 2-D contour surfaces of snow-cover duration as a function of winter (December-January-February, or DJF). Average minimum temperature and precipitation for all selected climatological sites.

Explanation: Ellipses show the $2 \sigma$ (standard deviation) range of DJF minimum temperature and precipitation, and corresponding spread of snow-cover duration for Engelberg, Arosa, and the Säntis. The slopes of the ellipses are related to the covariance of temperature and precipitation.

2-D Konturen-Oberflächen der Schneedeckendauer als Funktion der winterlichen Durchschnittstemperaturminima und des Niederschlags in ausgewählten klimatologischen Lagen.

Surfaces de contour 2-D de la durée de la couverture neigeuse en tant que fonction de la température et des précipitations minimales moyennes hivernales (décembre-janvier-février ou DJF), de l'ensemble des sites climatologiques sélectionnés.

Source: Beniston, Keller \& Goyette (2003)

Jungo 2002; Beniston, Keller \& Goyette 2002; Beniston \& Tol 1998; Beniston, Tol, Delécolle, Hoermann, Iglesias, Innes, McMichael, Martens, Nemesova, Nicholls, Toth, Kovats, Leemans \& Stojic 1998; Beniston \& Verstraete 2001; Giorgi, Hurrell, Marinucci \& Beniston 1997; Goyette, Beniston, Jungo, Caya \& Laprise 2001; Haeberli \& Beniston 1998; Haeberli \& Beniston 2001; Heino, Bràzdil, Førland, Tuomenvirta, Alexandersson, Beniston, Pfister, Rebetez, Rosenhagen, Rösner \& Wibig 1999; InNes, Beniston \& Verstraete 2000; Jungo \& BenisTon 2001; Jungo, Goyette \& Beniston 2002; Keller, Kienast \& Beniston 2000; Marinucci, Giorgi, BenISTON, Wild, TSCHUCK \& Bernasconi 1995; Rotach, Marinucci, Wild, Tschuck, Ohmura \& Beniston 1997.

\section{Human Geography at the University of Fribourg}

There are several mainstreams of research and teaching in human geography, one dealing with marginal regions, one with the socio-economic implications of desertification, and another with issues broadly related to territorial changes in the general context of globalization.

Over the past ten years, research in marginality and marginal regions has taken place within the IGU (International Geographic Union) Commission on Evolving Issues in Geographical Marginality and its forerunners. Traditionally, marginality has been considered exclusively from an economic perspective, but we have started to include social, political and ecological aspects in order to emphasize the breadth of the concept (Leimgruber 1994). Marginal can be defined as lying on the edge of a system (ANDREOLI 1992); it can also be seen as situated beyond the periphery, i.e., with little to no links to a center, and it can be defined as lying outside a mainstream process. It must not be interpreted as a static situation but as a temporary state in an ongoing process.

An important concern in our work has been the value system that underlies human perceptions, decisions, and actions. Values constantly oscillate between a 


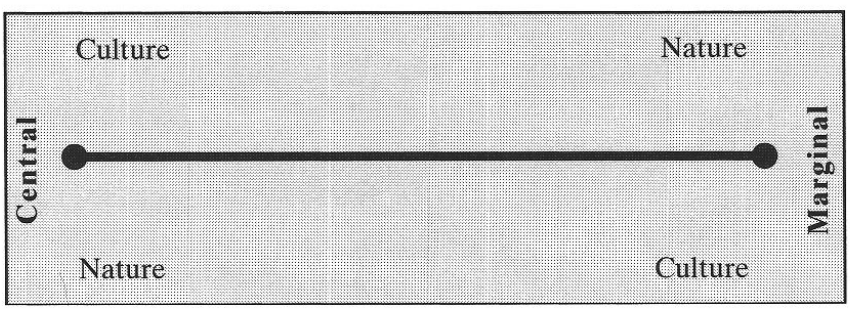

Fig. 3: The inversion of perspectives: conventional (above) and new way (below) of viewing marginality Die Umkehrung der Perspektiven: konventionelle (oben) und neuartige (unten) Sichtweise der Marginalität L'inversion des perspectives: démarches conventionnelle (en haut) et nouvelle (en bas) en matière de vision de la marginalité

Source: based on LeImgruber 2000, Fig. 5 and 6

«secular» and a «sacred» extreme, the former being best expressed by terms like innovation, exploitation, rationality, etc., whereas the latter are related to conservation and tradition, care, emotions, etc. At times we therefore privilege secular values, but at a later stage, the pendulum will swing back and sacred values will recover some of their importance. The transition from modernity to post-modernity is characterized by such a swing. The evolution of our worldview is a key element in this process (LeImgruber 2002b) (Fig. 3).

When proposing to focus on the ecological aspects of marginality, we actually had in mind the way people perceive nature/the ecosystem. The assumption that the environment was a no-cost-factor in pricing mechanisms has led to false calculations in the long run, which resulted in the degradation and destruction of many regions (LeIMGRUBER 2000). This attitude is also a danger for the capital of tourism, landscape, where architects have transferred urban type buildings into mountain landscapes with no regard for aesthetics (KRIPPENDORF 1984).

Marginal regions from the economic perspective have been looked upon as negligible, unsuited to modern production, a sort of region left over after modernity has swept across the land. The regions concerned were rural areas, particularly in the mountains. Abandoned land reverts to a natural state and is characterized by new and varied species. Biological diversity can thus be regained, although we have to be cautious with such a simple statement. From their observations in the Swiss alpine resort of Grindelwald, Nievergelt \& SCHIESS (1984: 9) concluded that the decision to abandon mowing and grazing «will cause fundamental changes in the ecosystem. All species typical of meadows will completely disappear, whereas woodland species will successively invade the area.» Thus, the rural exodus in particularly from mountain regions does not necessarily lead to an increase in biodiversity (LEIMGRUBER forthcoming a).

At the boundary between the physical science and the humanities is the problem of desertification. This phenomenon, that is leading to significant advances of the arid zone in many parts of the world, is generated by a complex set of inter-related natural, economic, societal, and political factors. A region of particular interest is the Sahelian zone of West Africa, where relatively small changes in environmental conditions have led to major negative consequences for resource use and desertification (HAMmer 1999, 2002). The research conducted over a number of years has attempted to address the issue of desertification through three fundamental aspects, namely the human and physical mechanisms underlying desertification (HAMmer 2001a); the possibilities for adaptation or mitigation strategies (HAMMER 2000a); and the assessment of programs aimed at combating desertification (Hammer 2001b).

Recent research has shown that issues related to desertification are highly complex and require detailed model concepts to address these issues (HAMmER 2001a). In addition, the solutions to the problem need to be handled at multiple levels of interdisciplinary science (HAMMER 2001c). Adaptation strategies require a portfolio of socio-cultural, socio-economic, political and technological approaches at local, regional, national, and supra-national levels (HAMmER $2000 \mathrm{~b} ; 2000 \mathrm{c}$ ). Although much progress has been made in arid zone research since the first international conference on desertification in 1977, there are still numerous areas of uncertainty that require further research within both the physical and the social sciences.

Another theme within the domain of human geography involves territorial changes that are analyzed in so far as they call for renewed socio-political regulations. Research in this field is mainly pragmatic in the sense that it is firstly based on observing the territorial behavior of actors who are members of the civil society in everyday life and, secondly, oriented towards the formulation of advice for public or private organizations in charge of their regulation. In addition, it also integrates theoretical considerations that emerge from political geography, anglo-saxon social geography, sociology and history, regulation theories, and institutional analyses. Research in these domains comprise three main avenues :

- Territories of modernity. These territories can be both urban and rural. In the case of Switzerland, they include urban agglomerations as well as urban outskirts. Territories of modernity are representative of our present lifestyles that are driven by 
disembedding mechanisms. The approach we are developing at the Department of Geosciences is linked to the work of CORBOZ, and his concept of «hyperville»(«hyper-cities»), SIEverts and his «Zwischenstädte» («cities-in-between»), or AscheR's «métapole». It is based on the hypothesis that prior to designing any new regulation it is necessary to properly understand the form and the meaning of these territories as well as the main forces that contribute to their production. This approach is developed through the European COST (Coopération Scientifique et Technique, a European funding mechanism) $\mathrm{C} 10$ Action, in partnership with Büro $Z$ in Zurich, and C.E.A.T. (Communauté d'Etudes de l'Aménagement du Territoire) in Lausanne.

- Linking institutional and relational territories. Based on territorial spreading linked to current lifestyles (relational territories), the question is to identify and to discuss various options open to public authorities in order to re-design institutional territories so that they are better «containers». For this purpose, institutional innovations such as agreements between Swiss cantons and associations or mergers between municipalities and urban areas are analyzed. For example, the Department of Geosciences and the Department of Political Economy received a mandate to assess the Fribourg law on agglomerations and the Fribourg public transportation system CUTAF (Communauté Urbaine des Transports de l'Agglomération Fribourgeoise). This work is a contribution to the Swiss administration's attempt to initiate and develop a Federal policy in favor of urban areas.

- CCTV monitoring of public places. Video-surveillance cameras have a symbolic and an information significance. They provide new forms of social regulation related to panoptical and disciplinary mechanisms. These new forms are likely to affect the representation and the behavior of persons under surveillance. But they are also likely to lead to the formulation of a new set of collective actions because they impose constraints and limits on privacy and individual rights, and they generate exclusion phenomena within public places. This theme is developed through the European COST A14 Action. As a result of problems and uncertainties related to methodological approaches, our research focuses on CCTV(Closed-Circuit TeleVision) designers and end-users. The next step will put more emphasis on people who are under surveillance. This project is carried out in partnership with the Department of Geography of the University of Geneva, together with Rives, a French laboratory of ENTPE (Ecole Nationale des Travaux Publics de l'Etat) in Lyon, and the Department of Geosciences of the University of Fribourg.
For further details see Bailly, Pellegrino, Hüsler \& Ruegg 2001; Dafflon \& Ruegg 2001; Dafflon \& Ruegg 2002; November, Klauser \& Ruegg 2000; RuegG, Comby \& Dousse 2001; Wiesmann, Woeffray, Ruegg \& Rey 2002.

\section{Geomatics}

Over the last few years, Geographic Information Science (GISc) has reached a mature stage as a recognised disciplinary field. As is the case with many methodological domains, GISc has oscillated between applied and theoretical foci. About thirty years ago, cartography and mapping of spatial phenomena began responding to the rapidly developing computer era, thus benefiting from automation, speed and storage capabilities of computers, as well as their rigid structural constraints. Following this trend, geographical database (GDB) developments began to emerge in order to link the spatial and temporal dimensions with the thematic ones. During this time, computerized acquisition processes of spatial information were developed in numerous applied disciplines such as remote sensed images, digitized maps and automated field measurements. Numerous applied and theoretical scientific fields also contributed to the development and the adaptation of spatial analysis methodologies during this period. With time, all of these diverse achievements slowly merged to form a coherent spatial information processing system, offered as a multidisciplinary environment. GISc now encompasses the full domain of spatial information processing. Its natural strength as a multidisciplinary tool is certainly due to the contribution of multiple disciplines to its development.

Geographical information science research topics within the Department of Geosciences follows different directions, but all are aimed at contributing to the development of spatial analysis methodologies, a fundamental concept within geography. As the case with many methodological domains, GISc is concerned with both conceptual and applied approaches, as well as with their multiple interactions.

For over two decades, the focus of research in this area was on the understanding and the integration of information process components that participate in the definition of a model of spatial reality. At the conceptual level, relevant contributions were made in the field of geographical information acquisition processes, particularly for the extraction of relevant information from remote sensed images (CAloz \& Collet, 2001; AbedNEGO \& Collet 1992), in the setting up of a methodological corpus for spatial analysis (Collet 1992; Dousse 2000) and in the transfer of geographical infor- 
mation reasoning to environmental sciences (COLLET et al. 1996; CAloz \& Collet 1997; KReIEnbüHL 1999). At the application level, research projects were successfully conducted in the fields of urban structures and dynamics (TerretTAz 1998; WebER et al. 1997) and land-cover changes (HE \& COLLET 1999).

We believe that GISc should be concerned with both conceptual and applied levels as their development and progress rely on an iterative process for validation and integration of methods. Current research at the Department of Geosciences at the University of Fribourg tends to confirm this viewpoint. Our participation in a Swiss «Virtual Campus» project (Geographic Information Technology Training Alliance, GITTA, 2001-2003), involving a consortium of seven higher education institutions, was aimed at integrating the scope of different scientific disciplines into a structured teaching corpus based on e-learning environments (WeIBEL 2000). Our involvement in various applied research projects in the field of climatic changes (HÄBERLI \& BENISTON 2001) and natural hazards assessment (RANDRIAMANGA 2000) provides challenging opportunities for developing and assessing methodologies within a multidisciplinary context.

\section{References}

Abednego, B. \& C. Collet (1992): A theoretical approach for vegetation change index based on noncorrected radiometric data. - In: International Journal of Remote Sensing 13, 4: 699-714.

ANDREOLI, M. (1992): An analysis of different kinds of marginal systems in a developed country: the case of Italy. - In: Occasional Papers in Geography and Planning 4: 24-44, Appalachian State University, Boone N.C.

Bailly, A., Pellegrino, P., Hüsler, W. \& J. Ruegg (éds) (2001): Grandes infrastructures de transports, forme urbaine et qualité de vie. - Paris: Economica, coll. Anthropos.

Baudraz, G. (1998): Gestion des géotopes géomorphologiques. - Mém. Dipl. en Géographie, Fribourg.

Beniston, M. (1997): Variations of snow depth and duration in the Swiss Alps over the last 50 years: links to changes in large-scale climatic forcings. - In: Climatic Change 36: 281-300.

Beniston, M. (2000a): Environmental Change in Mountains and Uplands. - London: Arnold/Hodder and Stoughton/Chapman and Hall Publishers, New York: Oxford University Press, 172 pp.

BENiston, M. (2000b): Environmental stresses on mountain ecosystems. Encyclopedia of Global Environmental Change (EGEC). - Chichester, New York: J. Wiley Publishers.

Beniston, M. (2001a): Effects of global warming on mountains. Encyclopedia of Life Support Systems
(EOLSS). - UNESCO Publications and EOLSS Publishers, Oxford, UK: 256-260.

Beniston, M. (2001b): Mountain meteorology, fundamentals and applications: A review. - In: Mountain Research and Development 21: 95-96.

Beniston, M. (2002a): Climatic Change - Implications for the Hydrological Cycle and for Water Management. - In: Beniston (ed.): Advances in Global Change Research. - Dordrecht/The Netherlands and Boston/ USA: Kluwer Academic Publishers, 503 pp.

Beniston, M. (2002b): Climate modeling at various spatial and temporal scales: Where can dendrochronology help? - In: Dendrochronologia 20:117-131.

Beniston, M.(2002c): Climatic change: Possible impacts on human health. - In: Swiss Medical Weekly 132: 332-337.

Beniston, M. (2003): Climatic change in mountain regions: a review of possible impacts. - In: Climatic Change 59, 5-31.

Beniston, M., Casals, P. \& M. Sarazin (2002): Perturbations to astronomical observations at the European Southern Observatory's very large telescope site in Paranal, Chile: analyses of climatological causes. In: Theor. and Appl. Clim. 73: 133-150.

Beniston, M., Diaz, H.F. \& R.S. Bradley (1997): Climatic change at high elevation sites: a review. - In: Climatic Change 36: 233-251.

Beniston, M., Fox, D.G., Adhikary, S., Andressen, R., Guisan, A., Holten, J., Innes, J., Maitima, J., Price, M. \& L. Tessier (1996): The Impacts of Climate Change on Mountain Regions. Second Assessment Report of the Intergovernmental Panel on Climate Change (IPCC), Chapter 5. - Cambridge: Cambridge University Press: 191-213.

Beniston, M., Haeberli, W. \& A. Taylor (1997): On the potential use of glacier and permafrost observations for verification of climate models. - Annals of Glaciol. 25: 400-406.

Beniston, M. \& W. Haeberli (2001): Sensitivity of mountain regions to climatic change. - In: LozAN, J.L., Grassl, H. \& P. Hupfer (eds): Climate of the $21^{\text {st }}$ Century: Changes and Risks. - Hamburg: GEO Publications: 237-244.

Beniston, M. \& J.L. InNes (1998): Impacts of climatic variability and extremes on forests: a synthesis. - In: Beniston, M. \& J.L. Innes (eds): The impacts of climate variability on forests. - Heidelberg, New York: Springer-Verlag: 309-318.

Beniston, M. \& P. Jungo (2002): Shifts in the distributions of pressure, temperature and moisture in the alpine region in response to the behavior of the North Atlantic Oscillation. - In: Theor. and Appl. Clim. 71: 29-42.

Beniston, M., Keller, F. \& S. Goyette (2002): Snow pack in the Swiss Alps under changing climatic conditions: an empirical approach for climate impacts studies. - Theor. and Appl. Clim. 74: 19-31. 
Beniston, M.\& R.S.J.ToL (1998): The potential impacts of climate change on Europe. - Energy and Environment 9: 365-381.

Beniston, M., Tol, R.S.J., Delécolle, R., Hoermann, G., Iglesias, A., Innes, J., McMichael, A.J., Martens, W.J.M., Nemesova, I., Nicholls, R., Toth, F.L., Kovats, S., Leemans, R. \& Z. Stojic (1998): Regional impacts of climatic change on Europe. Special Report of the Intergovernmental Panel on Climate Change (IPCC), Chapter 5. - Cambridge: Cambridge University Press: 149-185.

Beniston, M. \& M.M. Verstraete (eds) 2001: Remote Sensing and Climate Modeling. Synergies and Limitations. - In:Beniston, M. \& Verstraete (eds):Advances in Global Change Research, new series. - Dordrecht, Boston: Kluwer Academic Publishers, 356 pp.

BÉTRISEY S. (1997): La nature au service du développement durable. Rive droite de la vallée d'Hérens. Mém. Dipl. en Géographie, Fribourg.

Bloetzer, W., Egli, T., Petrascheck, A., Sauter, J. \& M. Stoffel (1998). Klimaänderungen und Naturgefahren in der Raumplanung - Methodische Ansätze und Fallbeispiele. - Synthesebericht NFP31, Zürich: vdf Hochschulverlag AG.

BoÉchat, M. (2002): Contribution à l'inventaire des géotopes du Canton du Jura. Eléments géomorphologiques remarquables du bassin de la Sorne. Mém. Dipl. en Géographie, Fribourg

Boyer, L., Fierz, S. \& M. Monbaron (1998): Geomorphological Heritage Evaluation in Karstic Terrains: A Methodological Approach Based on Multicriteria Analysis. - Suppl. du Geografia Fisica e Dinamica Quaternaria III, 4: 103-113.

CAloz, R. \& C. Collet (1997): Geographic Information Systems (GIS) and Remote Sensing in Aquatic Botany: Methodological Aspects. - Aquatic Botany 58: 209-228.

CAloz, R. \& C. Collet (2001):Traitements numériques d'images de télédétection. - Coll. Précis de télédétection 3, Sainte-Foy, Canada: Presses de l'Université du Québec / AUPELF, 386 pages.

COLLET, C.(1992): Systèmes d'information géographique en mode image. - Collection Gérer l'environnement 7, Lausanne: Presses Polytechniques et Universitaires Romandes, 186 pages.

Collet, C., Consuegra, D. \& F. Joerin (1996): Chapter 6: GIS Needs and GIS Software. - In: Singh, V.P. \& M. FioRENTINo (eds): Geographical Information Systems in Hydrology. - Dordrecht/The Netherlands: Kluwer Academic Publishers: 115-174.

Conus, D. (2002): Reconstitution de la fréquence des événements de laves torrentielles sur le cône du Ritigraben (VS), par des méthodes dendrogéomorphologiques. - Trav. Dipl. en Géographie, Fribourg.

Dafflon, B. \& J. RuegG (2001): Réorganiser les communes, créer l'agglomération. - Fribourg: Editions Universitaires Fribourg.
DAfFlon, B. \& J. Ruegg (2002): Innovation institutionnelle et logique «de bas-en haut»: la loi sur les agglomérations dans le canton de Fribourg (Suisse). Organisations et Territoires 11,3:127-135.

Delaloye, R. \& G. Devaud (2000): La distribution du pergélisol dans les marges proglaciaires des glaciers de Challand, d'Aget et du Sanetschhorn (Valais, Alpes suisses). - In: HegG, Ch. \& D. Vonder MüHLL (Hrsg.): Beiträge zur Geomorphologie. - Proceedings der Fachtagung der Schweizerischen Geomorphologischen Gesellschaft vom 8.-10. Juli 1999 in Bramois (Kt. Wallis), Birmensdorf, Eidgenössische Forschungsanstalt WSL: 89-96.

Delaloye, R. \& S. Morand (1998): Du Val Ferret au Grand-Combin (Alpes Valaisannes): Inventaire des glaciers rocheux et analyse spatiale du pergélisol à l'aide d'un SIG. - Beiträge aus der Gebirgs-Geomorphologie, Mitt. Wass. Hydr. Glaz., ETH-Zürich 158: 75-83.

Delaloye, R., Reynard, E., Lambiel, C., Marescot, L. $\&$ R. Monnet (2003): Thermal anomaly in a cold scree slope, Creux du Van, Switzerland. - Proceedings of the $8^{\text {th }}$ International Conference on Permafrost, Zurich 2003 (forthcoming).

Dousse, D. (2000): Utilisation des SIG en hydrologie pour la délimitation des bassins versants. - Master thesis, University of Fribourg, IGUF, Fribourg, 127 pages.

Dubey, B. (1998): Essai de détermination de sites propices à la viticulture au moyen d'un Système d'Information à Références Spatiales (SIRS). - Mém. Dipl. en Géographie, Fribourg.

Fierz, S. \& M. Monbaron (1999): Morphogenèse des Franches-Montagnes (Jura suisse). - Ecologae Geologicae Helvetiae 92: 199-210.

Froidevaux, V. (2002): Monographie géomorphologique de la partie orientale des Franches-Montagnes et du secteur de Montmelon - La Combe Charat. Contribution à l'inventaire des géotopes du Canton du Jura. - Mém. Dipl. en Géographie, Fribourg.

GardaZ, J.-M. (1998): Permafrost prospecting. Periglacial and rock glacier hydrology in mountain areas: case studies in the Valais Alps, Switzerland. - PhD Thesis, Univ. Press, Fribourg, Switzerland.

Gärtner, H. \& M. Stoffel (2002). Detailed mapping and dendrogeomorphological analysis of a debris flow torrent in Switzerland. - In: INTERPRAEVENT 2002, 1:199-207.

Gärtner, H., Stoffel, M., Lièvre, I. \& M. Monbaron (2003): Tree ring analysis and detailed geomorphological mapping on a forested debris flow cone in Switzerland. - 3rd International Conference on DebrisFlow Hazard Mitigation 2002 Davos, September 12-13 (under review).

Gerber, E. (1994): Geomorphologie und Geomorphodynamik der Region Lona-Sasseneire (Wallis, Schweizer Alpen) unter besonderer Berücksichtigung von Lockersedimenten mit Permafrost. - PhD Thesis, Fac. Sciences, Univ. Fribourg, Switzerland. 
Giorgi, F., Hurrell, J., Marinucci, M. \& M. Beniston (1997): Height dependency of the North Atlantic Oscillation Index. Observational and model studies. - J. Clim. 10:288-296.

Goyette, S., Beniston, M., Jungo, P., Caya, D. \& R. LAPRISE (2001): Numerical investigation of an extreme storm with the Canadian Regional Climate Model: the case study of windstorm Vivian, Switzerland, February 27, 1990. - In: Climate Dynamics 18: 145-168.

GRANDGIRARD, V. (1997): Géomorphologie, protection de la nature et gestion du paysage. - Thèse no 1163, Institut de Géographie, Université de Fribourg.

HaEberLI, W. \& M. Beniston (1998): Climate change and its impacts on glaciers and permafrost in the Alps. - Ambio 27:258-265.

Haeberli, W. \& M. Beniston (2001): Linking the different resolutions of regional climate and cryospheric impact models through advanced GIS techniques. COST-719 and OFES Project, Zurich and Fribourg.

Hammer, T. (1999): Desertifikation und Überlebensökonomie im Sahel. Das 3-Sektoren-Modell als theoretischer Erklärungsansatz? - In: Roost VISCHER, L., Mayor, A. \& D. Henrichsen (Hrsg.): Brücken und Grenzen - Passages et frontières. Le forum suisse des africanistes 2, Hamburg: LIT-Verlag: 87-99.

HAMmer, T. (2000a): Desertifikation im Sahel. Lösungskonzepte der Dritten Generation. - In: Geographische Rundschau 52,11:4-10.

HAMmer, T. (2000b): Strategie nachhaltiger Entwicklung der Sahel-Staatengemeinschaft CILSS. - In: Geographische Rundschau 52,11:18-26.

Hammer, T. (2000c): Sécurité alimentaire et gestion des ressources dans les pays du Sahel. Essai d'évaluation de la stratégie du CILSS. - In: StäUble Tercier, N. \& B. SotTas (éds): La sécurité alimentaire en questions. Dilemmes, constats et controverses. - Paris: Karthala: 247-257.

Hammer, T. (2001a): Politische Ökologie der Desertifikation. Ein Beitrag zum Erklärungs- und Lösungskomplex im Sahelraum. - In: Geo-Öko 22, 3: 79-90.

Hammer, T. (2001b): Desertifikationsbekämpfung im Rahmen von Entwicklungsprojekten. Eine Evaluation von Erfahrungen im westafrikanischen Sahel. - In: Standort, Zeitschrift für angewandte Geographie 25,3: 20-28.

Hammer, T. (2001c): Westafrika und der Sahel. Themenheft der Geographischen Rundschau 52, 11.

Hammer, T. (2002): Desertification and Migration. A Political Ecology of Environmental Migration in West Africa. - In: Krool, M. et al. (eds): Environmental Change: Implications for Human Migrations (forthcoming).

HäuselmanN, P. (2002): Cave Genesis and its Relationship to Surface Processes: Investigations in the Siebenhengste Region (BE, Switzerland). - Ph.D Thesis Geography, Fribourg + Höhlenforschergemeinschaft Region Hohgant HRH, 167 S.
Häuselmann, P., Jeannin, P.Y., Monbaron, M. \& S.E. LAURITZEN (2003): Reconstruction of Alpine Cenozoic paleo-relief through the analysis of Caves at Siebenhengste (BE, Switzerland). - Geodinamica Acta (in press).

Häuselmann, P., Jeannin P.Y. \& M. Monbaron (2003): Role of epiphreatic flow and soutirages in conduit morphogenesis: the Bärenschacht example. - Z.f. Geomorphologie, N.F. 47, 2: 171-190.

HäUselmann, P. \& M. Monbaron (2001): Cave Genesis in the Alpine Belt. - Proceedings of the First Workshop for Alpine Speleogenesis, Habkern, Sept., 10-13, 2000. UKPIK - Rapports de Recherche 10, Institut de Géographie de Fribourg, 156 p.

He, H. \& C. Collet (1999): Combining spectral and textural features for multispectral image classification with artificial neural networks. - In: International Archives of Photogrammetry and Remote Sensing, 32, Part 7-4-3 W6, Valladolid, Spain, June, 3-4, 1999: 175-181.

Heino, R., Brázdil, R., Førland, E., Tuomenvirta, H., Alexandersson, H., Beniston, M., Pfister, C., Rebetez, M., Rosenhagen, G., Rösner, S. \& J. Wibig (1999): Progress in the study of climatic extremes in Northern and Central Europe. - Climatic Change 42: 151-181.

InNes, J.L., Beniston, M. \& M.M. Verstraete (2000): Interactions between biomass burning and climate: a workshop synthesis. - In: InNes, J.L., Beniston, M. \& M.M. VerSTRAETE (eds): Biomass Burning and its Interrelationships with the Climate System. - Advances in Global Change Research, new series, Dordrecht, Boston: Kluwer Academic Publishers: 341-346.

JeAnbourquin, S. (1999): Projet de sentier didactique géomorphologique dans les Franches-Montagnes. Mém. Dipl. en Géographie, Fribourg

Jungo, P. \& M. BEnISTON (2001): Changes in the anomalies of extreme temperature anomalies in the $20^{\text {th }}$ Century at Swiss climatological stations located at different latitudes and altitudes. - Theor. and Appl. Clim. 69:1-12.

Jungo, P., Goyette, S. \& M. Beniston (2002): Daily wind gust speed probabilities over Switzerland according to three types of synoptic circulation. - Int. Journal of Clim. 22: 485-499.

Keller, F., Kienast, F. \& M. Beniston (2000): Evidence of the response of vegetation to environmental change at high elevation sites in the Swiss Alps. Regional Env. Change 2: 70-77.

KREIENBÜHL, C. (1999): Etude de la variabilité spatiale du cadmium dans les sols agricoles du canton de Fribourg. - Master thesis, University of Fribourg, IGUF, Fribourg, 165 pages.

KRIPPENDORF,J. (1984): The capital of tourism in danger. - In: Brugger, E.A., Furrer G., Messerli B. \& P. Messerli (eds): The transformation of Swiss mountain regions. - Bern: Paul Haupt Verlag: 427-450.

LEHMANN S. (1997): Pour une géomorphologie buisson- 
nière. Des géotopes à la rencontre du public. L'exemple d'un sentier didactique dans la réserve naturelle du Vanil Noir (Préalpes fribourgeoises, Suisse). - Mém. Dipl. en Géographie, Fribourg.

LEIMGRUBER W. (1994): Marginality and marginal regions: problems of definition. - In: CHANG-YI D. ChANG (ed.): Marginality and development issues in marginal regions. - Proceedings of the IGU Study Group «Development issues in marginal regions», Taipei, National Taiwan University: 1-18.

LEIMGRUBER, W. (2000): Land use and abuse: on the ecological and spiritual marginalization of land. - In: Majoral, R., Jussila, H. \& F. Delgado-Cravidão (eds): Environment and marginality in geographical space. Issues of land use, territorial marginalization and development in the new millennium. - Aldershot: Ashgate: 7-24.

LeIMGRUBeR, W. (2002a): Marginality and diversity. Do marginal regions ensure biological and cultural diversity? - Paper presented at the $29^{\text {th }}$ International Geographical Congress, Joint Meeting IGU Commission on the Dynamics of Marginal and Critical Regions and Commission on the History of Geographical Thought, Seoul, August 2000 (forthcoming).

Leimgruber, W. (2002b): Values, migration, and environment. An essay on driving forces behind human decisions and their consequences. - Paper presented at the International Workshop «Environmental Change: Implications for Population Migrations», Wengen/Switzerland, September, 19-22, 2001 (forthcoming).

LiÈvre, I. (2002): Détermination de la fréquence de laves torrentielles sur le torrent du Ritigraben (Valais, Suisse). - Trav. dipl. Géographie, Fribourg.

LugON, R. (1998): Evolution du pergélisol alpin face aux changements climatiques, études de cas dans les Alpes valaisannes (Suisse). - PhD Thesis, Fac. Sciences, Univ. Fribourg, Switzerland.

Marinucci, M.R., Giorgi, F., Beniston, M., Wild, M., Tschuck, P. \& A. Bernasconi (1995): High resolution simulations of January and July climate over the Western Alpine region with a nested regional modeling system. - Theor. and Appl. Clim. 51:119-138.

Menoud, D. (1997): Analyse et réflexion sur l'évolution en nombre et en taille des zones humides du Canton de Fribourg. - Mém. Dipl. en Géographie, Fribourg.

Nievergelt, B. \& H. Schiess (1984): Animal response to land-use changes in Grindelwald, Switzerland. Mountain Research and Development 4, 1: 5-14.

November V., Klauser, F. \& J. Ruegg (2000): Risques sous surveillance: une analyse géographique de l'utilisation de la vidéosurveillance. - Ethique publique 2: 43-50.

Pedrazzini, D. (2002): Campo e la sua frana: progetto per un sentiero didattico. - Mém. Dipl. en Géographie, Fribourg.

Perritaz, L. (1995): Contribution à l'étude géomor- phologique et hydrogéologique d'un karst perché en domaine méditerranéen: le plateau des Aït Abdi (Haut Atlas central calcaire, Maroc). - Thèse no 1102, Fac. des Sciences, Fribourg.

Perritaz, L. \& M. Monbaron (1998): Geomorphological Approach to the Aitt Abdi Plateau (Central High Atlas, Morocco). - In: Z. f. Geomorphologie N.F., Suppl.-Bd. 109: 83-104.

RANDRIAMANGA, S. (2000): Etude par télédétection des géorisques dans la région d'Anjojorobe, Madagascar. Action de recherche partagée,ARP1.10.04.01.1/00.28.1, Réseau thématique de recherche télédétection, AUF.

Reber S. (2001): Rund um den Schwarzsee. Ein Lehrpfad mit Zusatzwanderungen. - Mém. Dipl. en Géographie, Fribourg.

Reynard, E., Delaloye, R., Baron, L., Chapellier, D., Devaud, G., Lambiel, C., Marescot, L. \& R. Monnet (2003): Glacier/permafrost relationships in recently deglaciated forefields of small alpine glaciers, Penninic Alps, Valais, Western Switzerland. - Proceedings of the $8^{\text {th }}$ International Conference on Permafrost, Zurich 2003 (forthcoming).

Rotach, M.W., Marinucci, M.R., WiLD, M., TsChUCK, P., Ohmura, A. \& M. Beniston (1997): Nested regional simulations of climate change over the Alps for the scenario of a doubled greenhouse forcing. - In: Theor. and Appl. Clim. 57: 209-227.

Ruegg, J., Comby, P. \& D. Dousse (2001): NTIC, mouvements sociaux et nouvelles territorialités. - In: Vodoz, L. (éd.): NTIC et territoires: enjeux territoriaux des nouvelles technologies de l'information et de la communication, Lausanne: PPUR: 265-283.

Stoffel, M. \& M. Monbaron (2000): Changements climatiques et dangers naturels: Un défi pour l'aménagement du territoire en zone alpine. - 5e Colloque transfrontalier Cluse: Risques majeurs: perception, globalisation et management. Université de Genève, 20 et 21 septembre 2000, Genève.

Stoffel, M. (1999): Impacts of climate change on natural hazards and land use in the Saas and Zermatt Valleys (Switzerland). - In: Geographica Helvetica 54, 4: 224-228.

Stoffel, M. (2000): Impacts of climate change and natural hazards on land use in the Saas and Zermatt Valleys (Switzerland). - In: SingH, R.B., Fox, J. \& H. YukIO (eds): Land Use and Cover Change, Enfield NH: Science Publishers Inc.: 269-277.

Stoffel, M., Gärtner, H., Lièvre, I. \& M. Monbaron (2003): Comparison of reconstructed debris flow event years (Ritigraben, Switzerland) and existing flooding data. - 3rd International Conference on Debris-Flow Hazard Mitigation 2002, Davos, September 12-13 (under review).

Tenthorey, G. (1993): Paysage géomorphologique du Haut-Val de Réchy (Valais, Suisse) et hydrologie liée aux glaciers rocheux. - PhD Thesis, Fac. Sciences, Univ. Fribourg, Switzerland. 
Terrettaz, P. (1998): Délimitation des agglomérations et segmentation urbaine à l'aides d'images satellitales SPOT HRV. - PhD thesis, University of Fribourg, StPaul, Fribourg, 304 pages.

TuratTi, A. (2002): La discontinuité du pergélisol dans l'éboulis des Lapires (Nendaz/VS). - Master Thesis, Fac. Sciences, Univ. Fribourg, Switzerland.

Vonder Mühll, D., Delaloye, R., Haeberli, W., Hoelzle, M. \& B. Krummenacher (2001): Permafrost Monitoring Switzerland PERMOS. - 1. Jahresbericht 1999/2000. Glaziologische Kommission, Schweizerische Akademie der Naturwissenschaften SANW, Bern.

Weber, C., Donnay, J.P. \& C. Collet (1997): Reconnaissance des formes urbaines: transfert méthodologique Nord-Sud. - In: Dubois, J.-M. et al. (réd.): Télédétection des milieux urbains et périurbains, Montréal: Éditions AUPELF-UREF: 133-144.

WeIBEL, R. (2000): GITTA - Geographic Information Technology Training Alliance. - Project Proposal for Swiss Virtual Campus, Conférence Universitaire Suisse, OFES, Berne.

Wiesmann, C., Woeffray, B., Ruegg, J. \& M. Rey (2002): De la politique d'aménagement du territoire à la politique de développement territorial: plaidoyer pour la formation et la recherche en management territorial. - In: DISP 148, 1:33-37.

Prof. Dr. Martin Beniston, Prof. Dr. Claude Collet, PD Dr. Thomas Hammer, Prof. Dr. Walter Leimgruber, Prof. Dr. Michel Monbaron, Prof. Dr. Jean Ruegg, Department of Geosciences, Geography Unit, University of Fribourg, Pérolles, CH-1700 Fribourg.

\section{Internet addresses}

Département de Géosciences, Géographie:

http://www.unifr.ch/geoscience/geographie/

\section{Géomatique:}

http://www.unifr.ch/geoscience/geographie/Research/ Geomatics/Geomatics02-1.html

Développement durable, pays en voie de développement:

http://www.unifr.ch/geoscience/geographie/Research/ HUMAN/TH/TH.html

Frontières, régions marginales, migration:

http://www.unifr.ch/geoscience/geographie/Research/

HUMAN/WL/bound.html

Géographie socio-culturelle:

http://www.unifr.ch/geoscience/geographie/Research/ HUMAN/JR/Cost14.htm

Biogéographie:

http://www.unifr.ch/geoscience/geographie/Research/ PHYSICAL/BIOGEO/biogeogr.html

Géomorphologie et paysage:

http://www.unifr.ch/geoscience/geographie/Research/ PHYSICAL/GEOMORP/geomor.html

Climat et changements climatiques:

http://www.unifr.ch/geoscience/geographie/Research/ PHYSICAL/CLIMATO/Climate.htm 